\title{
mtDNA variation of the critically endangered hawksbill turtle (Eretmochelys imbricata) nesting on Iranian islands of the Persian Gulf
}

\author{
M. Tabib, H. Zolgharnein, M. Mohammadi, M.A. Salari-Aliabadi, \\ A. Qasemi, S. Roshani, H. Rajabi-Maham and F. Frootan \\ Department of Marine Biology, Faculty of Marine and Oceanic Science, \\ Khorramshahr Marine Science and Technology University, Khorramshahr, Iran \\ Corresponding author: H. Zolgharnein \\ E-mail: zolgharnein@kmsu.ac.ir
}

Genet. Mol. Res. 10 (3): 1499-1503 (2011)

Received November 10, 2010

Accepted January 3, 2011

Published July 25, 2011

DOI 10.4238/vol10-3gmr1148

\begin{abstract}
Genetic diversity of sea turtles (hawksbill turtle) was studied using sequencing of mitochondrial DNA (mtDNA, D-loop region). Thirty dead embryos were collected from the Kish and Qeshm Islands in the Persian Gulf. Analysis of sequence variation over 890 bp of the mtDNA control region revealed five haplotypes among 30 individuals. This is the first time that Iranian haplotypes have been recorded. Nucleotide and haplotype diversity was 0.77 and 0.001 for Qeshm Island and 0.64 and 0.002 for Kish Island, respectively. Total haplotype diversity was calculated as 0.69 , which demonstrates low genetic diversity in this area. The data also indicated very high rates of migration between the populations of these two islands. A comparison of our data with data from previous studies downloaded from a gene bank showed that turtles of the Persian Gulf migrated from the Pacific and the Sea of Oman into this area. On the other hand, evidence of migration from populations to the West was not found.
\end{abstract}

Key words: Genetic diversity; Sea turtles; Persian Gulf; D-loop; Mitochondrial gene; Phylogenetic analysis 


\section{INTRODUCTION}

Marine chelonians have inhabited the earth for over 100 million years, since the Cretaceous (Hirayama, 1998), and the fossil record reveals that four families were established during this period, two of which have survived to the present (Pritchard, 1996). The Dermochelyidae consists of only the leatherback turtle, Dermochelys coriacea, while the second family, the Cheloniidae, is commonly thought to include six species classified into five genera (Bowen and Karl, 2007). Of the five sea turtle species, the loggerhead, green olive Ridley, leatherback and hawksbill turtles, are reported to occur in the Persian Gulf. The hawksbill is critically endangered among the Persian Gulf marine turtles, which nest on the beaches of the mainland and islands of Iran (Mobaraki, 2004).

The hawksbill was first listed as an endangered species by the International Union for the Conservation of Nature, now the World Conservation Union (IUCN, 1968), and retained this listing in all subsequent publications of the Red List until 1996, when its status was changed to critically endangered (Groombridge and Luxmoore, 1989; Baillie and Groombridge, 1996).

The hawksbill sea turtle, Eretmochelys imbricata, is a circum-tropical species that is listed as critically endangered in the IUCN Red Book of Threatened Species (IUCN, 2009).

Genetic studies of nesting and foraging hawksbill turtles have been conducted in both the Indo-Pacific and Atlantic basins (Broderick et al., 1994; Broderick and Moritz, 1996; Bass, 1996; Bowen et al., 1996; Koike et al., 1996; Okayama et al., 1996). These studies are the first attempts to document in-depth genetics research on this endangered animal. Most of these studies have used sequences of the control region in the mitochondrial DNA (mtDNA) genome, with the intention of resolving the genetic structure of hawksbill populations. The mtDNA data have been used to test hypotheses concerning reproductive behavior and the composition of foraging populations, and to infer patterns of migration and population structure.

\section{MATERIAL AND METHODS}

In this study, 30 dead embryos of loggerhead turtles were collected from the islands of Qeshm and Kish, and samples were fixed in 96\% ethanol. DNA was extracted from $0.1 \mathrm{~g}$ liver and muscle tissues, digested overnight at $56^{\circ} \mathrm{C}$ in a $1 \mathrm{X}$ TE buffer, $0.5 \mathrm{mg} / \mathrm{mL}$ proteinase $\mathrm{K}$ and $0.01 \%$ SDS solution, using standard phenol-chloroform (Hillis and Moritz, 1990). An 890-bp portion of the mtDNA D-loop and tRNA Pro was amplified by polymerase chain reaction (PCR) using the H950 (5'-GTCTCGGATTTAGGGGTTTG-3') and LCM15382 (5'-GCTTAACCCTAAAGCATTGG-3') primers (Laurent et al., 1998). Amplifications were performed in a total volume of $25 \mathrm{~mL}$ containing 5-50 ng whole DNA, $10 \mathrm{mM}$ of each dNTP, 10 pmol of each primer, $0.5 \mathrm{U}$ super Taq polymerase (Fermentas) and the corresponding reaction buffer (1X). Cycling parameters were $94^{\circ} \mathrm{C}$ for $5 \mathrm{~min}$, followed by 35 cycles at $94^{\circ} \mathrm{C}$ for $60 \mathrm{~s}, 53^{\circ} \mathrm{C}$ for $90 \mathrm{~s}$, and $72^{\circ} \mathrm{C}$ for $60 \mathrm{~s}$, and a final extension at $72^{\circ} \mathrm{C}$ for 5 min. Sequence alignments were performed with the Clustal W software (Thompson et al., 1994), and haplotype and nucleotide diversity were calculated using Arlequin v. 2. Phylogenetic relationships between turtles in the Persian Gulf islands and other areas in the world were determined by the Mega software. 


\section{RESULTS}

Sequence analysis of the 30 samples revealed 9 variable positions, defining 4 polymorphs and 5 haplotypes (Table 1). None of these haplotypes has ever been reported before. Therefore, all new haplotypes recorded in the NCBI gene bank as Iran1, 2, 4, 5, and 6 with accession Nos. GU997695 for Kish Island, GU997697, GU997698 and GU997699 for Qeshm Island, and haplotype Iran1 No. GU997694 was common between the two islands. Haplotype and nucleotide diversity was reported as 0.77 and 0.001 for Qeshm Island and 0.64 and 0.002 for Kish Island, respectively (Table 2). Haplotype diversity $(h)$ varied from 0.77 to 0.64 , similar to estimates for other marine turtle species (Table 2). Nucleotide diversity $(\pi)$ varied from 0.001 to 0.002 .

\begin{tabular}{|c|c|c|c|c|}
\hline \multirow[t]{2}{*}{ Haplotypes } & \multicolumn{4}{|c|}{ Base position } \\
\hline & 163 & 165 & 166 & 484 \\
\hline Iran1 & $\mathrm{T}$ & $\mathrm{C}$ & $\mathrm{T}$ & $\mathrm{G}$ \\
\hline $\operatorname{Iran} 2$ & $\mathrm{~T}$ & $\mathrm{C}$ & $\mathrm{C}$ & $\mathrm{G}$ \\
\hline Iran4 & $\mathrm{T}$ & $\mathrm{C}$ & $\mathrm{T}$ & A \\
\hline Iran5 & $\mathrm{G}$ & $\mathrm{C}$ & $\mathrm{T}$ & $\mathrm{G}$ \\
\hline Iran6 & $\mathrm{T}$ & $\mathrm{T}$ & $\mathrm{T}$ & G \\
\hline
\end{tabular}

Table 2. Haplotype $(h)$ and nucleotide $(\pi)$ diversities for two populations of the hawksbill turtle in the Persian Gulf.

\begin{tabular}{lcc}
\hline Location & Haplotype diversity $(\mathrm{h})$ & Nucleotide diversity $(\pi)$ \\
\hline Qeshm & 0.77 & 0.001 \\
Kish & 0.64 & 0.002 \\
Overall & 0.69 & 1.56 \\
\hline
\end{tabular}

The phylogenetic analysis based on the mtDNA D-loop sequences was able to discriminate the two main lineages using a neighbor-joining phylogenetic tree program (Figure 1).

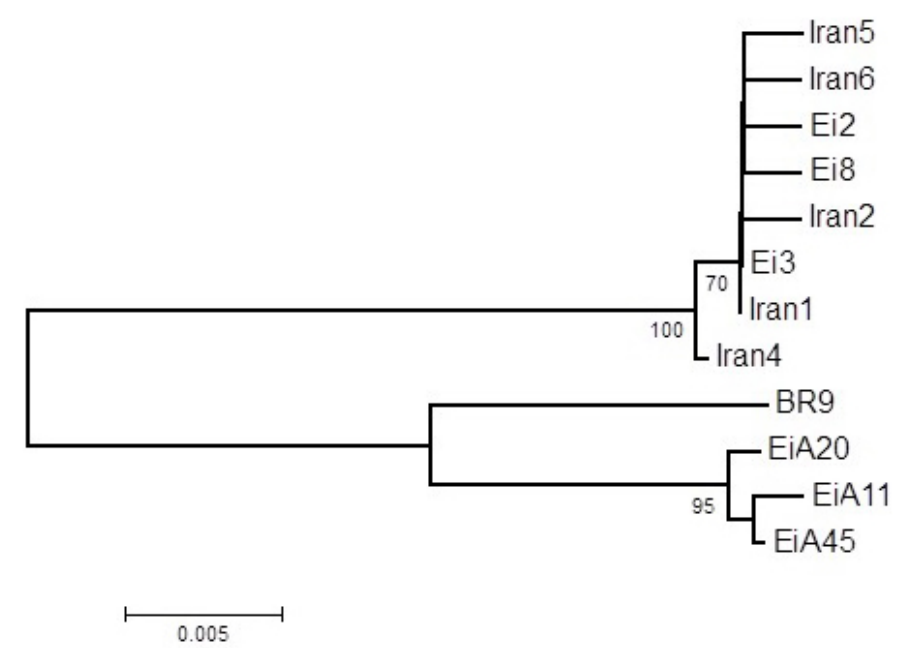

Figure 1. Neighbor-joining tree based on the mtDNA D-loop sequences. Bootstrap values (1000 replicates) are indicated on the branches. Two clades of haplotypes were identified, called 1 and 2, respectively. Haplotypes EiA11 and BR9 are nested in the Atlantic Ocean. Haplotypes Iran1, 2, 4, 5, and 6 and Ei2, 3, 8 are nested in the Indo-Pacific Ocean. 
Bootstrap values (1000 replicates) are indicated on the branches. Neighbor-joining analysis revealed the presence of two clades, designated clades A and B. Two clades of haplotypes were identified in the Persian Gulf, the Indo-Pacific Ocean and the Atlantic Ocean. Clade A belonged to haplotypes Iran1, 2, 4, 5, 6, and to haplotypes from the Indo-Pacific Ocean, Ei2, 3, 8. Clade 2 belonged to haplotypes EiA11, EiA20, EiA45 (Velez-Zuazo et al., 2008) and BR9 (Lara-Ruiz et al., 2006) from the Atlantic Ocean.

\section{DISCUSSION}

Genetic investigations of nesting populations in the marine turtles identified fixed or nearly fixed variations in mtDNA haplotype frequencies among rookeries (Bowen et al., 1993; Encalada et al., 1998; Maffucci et al., 2006). Two forms of evidence include tagging data and mtDNA data and show that natal homing predominates, but breeding populations may involve several proximal nesting sites (Bowen and Karl, 2007). This result points out that genetically distinct reproductive units are also demographically independent and must be managed individually (Schroth et al., 1996; Bowen, 2003). Some sea turtle nestings separated by a few hundred kilometers are not different in terms of haplotype frequencies (Broderick et al., 1994; Bass, 1996). The present study revealed five endemic haplotypes in the Persian Gulf rookeries, creating a unique Iranian haplotype profile. The results established a new subpopulation of hawksbill turtle in this area.

Our data analysis detected a relationship between the Indo-Pacific hawksbill turtle and the Persian Gulf hawksbill turtle. This agreed with Kinunen and Walczak (1971), who showed that the Iranian hawksbill turtle in the Persian Gulf belongs to the Indian hawksbill turtle. The hawksbill turtle also has two distinct lineages, corresponding to the Atlantic and Indo-Pacific (Okayama et al., 1999), but with a younger lineage in the East Atlantic, which is affiliated with the Indian Ocean.

Bourjea et al. (2007) found genetic differentiation among sites more than $500 \mathrm{~km}$ apart but not less than $150 \mathrm{~km}$ in the southwestern Indian Ocean. Our results indicated that the nested marine turtles on Qeshm Island near the Strait of Hormuz and Indo-Pacific Ocean also have a strong relationship with the Indo-Pacific Ocean and the Persian hawksbill turtle lineages. It means they are the same population because of the proximity of these areas, which facilitated migration and gene flow between the hawksbill turtle populations. On the other hand, the hawksbill turtles in the Atlantic and Pacific are separated from the two mentioned areas. Our phylogenetic results substantiated and extended findings of previous molecular phylogenetic studies, which also revealed two distinct lineages, corresponding to the Atlantic and Indo-Pacific (Okayama et al., 1999). The combined evidence from tagging data and mtDNA data indicate that natal homing predominates, but breeding populations may encompass several proximal nesting sites (Bowen and Karl, 2007).

The results obtained from data analysis showed higher genetic diversity among the hawksbill turtle population on Qeshm Island than Kish Island. This indicates that important essential factors exist on the beach of Qeshm Island, more appropriate than on Kish Island. It should be noted that proper protection of Qeshm Island and the good environment situation facilitated marine turtle spawning on that island. The low genetic variation found throughout the Persian Gulf is in line with increased coastal development, expansion of human settlements, industrialization, and industrial waste, which threaten marine turtle habitat. 


\section{REFERENCES}

Baillie J and Groombridge B (1996). IUCN Red List of Threatened Animals. IUCN, Gland, Switzerland and Cambridge.

Bass AL (1996). Application of Isolation by Distance Models to Hawksbill Turtle (Eretmochelys imbricata) Nesting Sites in the Caribbean. In: Proceedings of the International Symposium on Sea Turtle Conservation Genetics (Bowen BW and Witzell WN, eds.). NOAA Technical Memorandum. National Marine Fisheries Service, Southeast Fisheries Science Center, 396, Miami, 41-46.

Bourjea J, Lapegue S, Gagnevin L, Broderick D, et al. (2007). Phylogeography of the green turtle, Chelonia mydas, in the Southwest Indian Ocean. Mol. Ecol. 16: 175-186.

Bowen BW (2003). What is a Loggerhead Turtle? The Genetic Perspective. In: Loggerhead Sea Turtles (Bolten AB and Witherington BE, eds.). Smithsonian Institution Press, Washington, 7-27.

Bowen BW and Karl SA (2007). Population genetics and phylogeography of sea turtles. Mol. Ecol. 16: 4886-4907.

Bowen BW, Avise JC, Richardson JI, Meylan AB, et al. (1993). Population structure of loggerhead turtles (Caretta caretta) in the northwestern Atlantic Ocean and Mediterranean Sea. Conserv. Biol. 7: 834-844.

Bowen BW, Bass AL, Garcia-Rodriguez A, Diez CE, et al. (1996). Origin of hawksbill turtles in a Caribbean feeding area as indicated by genetic markers. Ecol. Appl. 6: 566-572.

Broderick D and Moritz C (1996). Hawksbill Breeding and Foraging Populations in the Indo-Pacific Region. In: Proceedings of the International Symposium on Sea Turtle Conservation Genetics (Bowen BW and Witzell WN, eds.). NOAA Technical Memorandum. National Marine Fisheries Service, Southeast Fisheries Science Center, 396, Miami, 119-128.

Broderick D, Moritz C, Miller JD, Guine M, et al. (1994). Genetic studies of the Hawksbill turtle (Eretmochelys imbricate): evidence for multiple stocks in Australian waters. Pacific Conserv. Biol. 1: 123-131.

Encalada SE, Bjorndal KA, Bolten AB, Zurita JC, et al. (1998). Population structure of loggerhead turtle (Caretta caretta) nesting colonies in the Atlantic and Mediterranean as inferred from mitochondrial DNA control region sequences. Mar. Biol. 130: 567-575.

Groombridge B and Luxmoore R (1989). The Green Turtle and Hawksbill (Reptilia: Cheloniidae): World Status, Exploitation, and Trade. CITES Secretatiat, Lausanne.

Hillis DM and Moritz C (1990). Molecular Taxonomy. Sinauer Associates Inc. Publishers, Sanderland.

Hirayama R (1998). Oldest known sea turtle. Nature 392: 705-708.

IUCN (1968). Classifications of Rare and Endangered Forms. In: Survival Service Commission Red Data Book. IUCN, Morges.

IUCN (2009). The IUCN Red List of Threatened Species. Available at [http://www.iucnredlist.org]. Accessed July 2011.

Kinunen W and Walczak PS (1971). Persian Gulf Sea Turtle Nesting Surveys. Job Completion Rept., Division of Research Development, F7-F50.

Koike H, Okayama T, Baba Y, Diaz R, et al. (1996). Conservation Genetics for the CITES-Listed Animals - Mitochondrial DNA Analysis Using the Scutes of Hawksbill Turtles. International Symposium on Network and Evolution of Molecular Information, Tokyo.

Lara-Ruiz P, Lopez GG, Santos FR and Soares LS (2006). Extensive hybridization in hawksbill turtles (Eretmochelys imbricata) nesting in Brazil revealed by mtDNA analyses. Conserv. Genet. 7: 773-781.

Laurent L, Casale P, Bradai MN, Godley BJ, et al. (1998). Molecular resolution of marine turtle stock composition in fishery bycatch: a case study in the Mediterranean. Mol. Ecol. 7: 1529-1542.

Maffucci F, Kooistra WHCF and Bentivegna F (2006). Natal origin of loggerhead turtles, Caretta caretta, in the neritic habitat off the Italian coasts, Central Mediterranean. Biol. Conserv. 127: 183-189.

Mobaraki A (2004). Nesting of the hawksbill turtle in Shidvar Island, Hormozgan Province, Iran. Mar. Turtle Newsl. 103: 13.

Okayama T, Diaz R, Koike H, Diez CE, et al. (1996). Mitochondrial DNA Analysis of the Hawksbill Turtle. I. Haplotype Detection Among Samples in the Pacific and Atlantic Oceans. International Symposium on Network and Evolution of Molecular Information, Tokyo.

Okayama T, Diaz-Fernandez R, Baba Y, Halim M, et al. (1999). Genetic diversity of the hawksbill turtle in the IndoPacific and Caribbean regions. Chelonian Conserv. Biol. 3: 362-367.

Pritchard PCH (1996). Evolution, Phylogeny and Current Status. In: The Biology of Sea Turtles (Lutz PL and Musick JA, eds.). CRC Press, Florida, 1-28.

Schroth W, Streit B and Schierwater B (1996). Evolutionary handicap for turtles. Nature 384: 521-522.

Thompson JD, Higgins DG and Gibson TJ (1994). CLUSTAL W: improving the sensitivity of progressive multiple sequence alignment through sequence weighting, position-specific gap penalties and weight matrix choice. Nucleic Acids Res. 22: 4673-4680.

Velez-Zuazo X, Ramos WD, van Dam RP, Diez CE, et al. (2008). Dispersal, recruitment and migratory behaviour in a hawksbill sea turtle aggregation. Mol. Ecol. 17: 839-853.

Genetics and Molecular Research 10 (3): 1499-1503 (2011)

CFUNPEC-RP www.funpecrp.com.br 